\title{
Development, production, and quality of 'Chonto' type tomato grafted on cherry tomato introductions ${ }^{1}$
}

\author{
Didier Alexander Franco ${ }^{2}$, Juan Felipe Arango ${ }^{2}$, Alejandro Hurtado-Salazar ${ }^{2}$,Nelson Ceballos-Aguirre ${ }^{2 *}$
}

10.1590/0034-737X201865020006

\begin{abstract}
Currently, tomato is one of the most cultivated crops worldwide, with the highest economic value, increasing its demand and, thus, its expansion, production, and trade. The tomato crop is susceptible to attack of pathogens with devastating consequences on the decline in yields from 50 to $100 \%$. For this reason, new production methods are proposed such as grafting in wild rootstocks, which have high genetic variability and genes responsible for resistance to fungi, bacteria, viruses, and nematodes. The aim of this study was to evaluate the effect of grafting commercial tomato cultivars onto cherry tomato genotypes on yield and fruit quality. The experiment was arranged in a completely randomized design with four replications. The experimental unit consisted of four plants. spaced at $0.9 \mathrm{~m}$ between rows (channels), $0.30 \mathrm{~m}$ between double rows, and $0.4 \mathrm{~m}$ between plants. The treatments consisted of the combination of the following factors: three promising rootstocks (IAC391, IAC426, and LA2076), two commercial scions (Calima and Torrano), two grafting methods (cleft and splice), and two ungrafted commercial controls. Yield components, soluble solids content, percentage of fruit quality, and average fruit weight were evaluated. IAC391 was the most promising rootstock, reaching productions similar to those of the controls. The cleft grafting method, reached a success rate of 98.3\%. The commercial scion Torrano stood out for achieving the highest yields.
\end{abstract}

Keywords: cleft; splice; Torrano; Calima; rootstock.

\section{RESUMO}

\section{Desenvolvimento, produção e qualidade de tomate 'Chonto' enxertado em acessões de tomate cereja}

Atualmente, o tomate é uma das culturas mais cultivadas no mundo, com o maior valor econômico, aumentando sua demanda e, assim, sua expansão, produção e comercialização. A cultura do tomate é suscetível ao ataque de patógenos com consequências devastadoras no declínio da produtividade de 50 para 100\%. Por esta razão, novos métodos de produção são propostos, como o uso de porta-enxertos selvagens, que possuem alta variabilidade genética e genes responsáveis pela resistência a fungos, bactérias, vírus e nematoides. O objetivo deste trabalho foi avaliar o efeito do enxerto de cultivares comerciais de tomateiro sobre genótipos de tomateiro em produtividade e qualidade de frutos. $\mathrm{O}$ experimento foi organizado em delineamento inteiramente casualizado com quatro repetições. A unidade experimental consistiu em quatro plantas, espaçadas a 0,9 m entre linhas (canais), $0,30 \mathrm{~m}$ entre linhas duplas e $0,4 \mathrm{~m}$ entre plantas. Os tratamentos consistiram da combinação dos seguintes fatores: três porta-enxertos promissores (IAC391, IAC426 e LA2076), dois enxertos comerciais (Calima e Torrano), dois métodos de enxertia (fenda e inglês simples) e dois controles comerciais não enxertados. Os componentes de rendimento, teor de sólidos solúveis, porcentagem de qualidade dos frutos e peso médio dos frutos foram avaliados. O IAC391 foi o porta-enxerto mais promissor, alcançando produções semelhantes às dos controles. O método de enxertia de fenda atingiu uma taxa de sucesso de $98,3 \%$. O enxerto comercial Torrano se destacou por alcançar os maiores rendimentos.

Palavras-chave: fenda; inglês simples; Torrano; Calima; porta enxerto.

\footnotetext{
Submitted on November $19^{\text {th }}, 2016$ and accepted on January $24^{\text {th }}, 2018$.

${ }^{1}$ This work is part of the research project Effect of the grafting of commercial tomato genotypes on fruit production and quality.

2 Universidad de Caldas, Departamento de Producción Agropecuaria, Universidad de Caldas, Manizales, Caldas, Colombia. didier.501122732@ucaldas.edu.co; juan.501121041@ucaldas.edu.co; alhuza@gmail.com; nelson.ceballos@ucaldas.edu.co

*Corresponding author: nelson.ceballos@ucaldas.edu.co
} 


\section{INTRODUCTION}

According to FAO (2013), Colombia reported a harvested area of tomato of $16.844 \mathrm{ha}^{-1}$ and, a production of $646.904 \mathrm{t}$, with an average yield of $38.4 \mathrm{t} \mathrm{ha}^{-1}$. The annual increase in production in recent years in Colombia is mainly due to an increase in yield, going from $21.7 \mathrm{tha}^{-1}$ in 2000 to $38.4 \mathrm{tha}^{-1}$ in 2013. The tomato crop in Colombia is grown throughout the country, in eighteen of the thirty-two departments; however, more than $80 \%$ of production is concentrated in the departments of Cundinamarca, Norte de Santander, Huila, Valle del Cauca, Santander, Tolima, Antioquia, Boyaca, Cesar, Nariño, Atlántico, and Guajira (Faostat, 2016). In 2007, the Department of Caldas had a planted area of $1,106 \mathrm{ha}^{-1}$ and yield of $47.8 \mathrm{t} \mathrm{ha}^{-1}$, taking a share in the domestic production of $12.77 \%$. In 2013, this area decreased $633 \mathrm{ha}^{-1}$, the yield to $32.4 \mathrm{t} \mathrm{ha}^{-1}$, and the share in the domestic production to $4.98 \%$. These data show an average negative annual growth rate of $14.54 \%$ for yield (Agronet, 2016).

Carrer et al. (2015) observed that the tomato crop is affected by various diseases of economic importance. Wilt, caused by Fusarium oxysporum f. sp. lycopersici (Sacc.) Snyder and Hansen (FOL), stands out as a major crop disease. Pathogenic fungi of the genus Fusarium, which are the causal agents of tomato wilt, cause root and basal stem deterioration and result in the wilting of vegetable plants (Van Dam et al., 2018). Another associated problem is nematode infestation. Cantu et al. (2009) mentioned that heavy infestations at the beginning of the crop may result in the death of the seedlings in the field and the production of the surviving plants become strongly affected in terms of both quantity and quality. Grafting technology can reduce the attack of soil pathogens and in turn makes plant adaptation to soil and climatic conditions possible. Grafting aims to find resistance to adverse conditions of biotic and abiotic factors and increase the quantity and quality of the fruit (HurtadoSalazar et al., 2015). One of the advantages of grafting is when crop rotation is not possible due to intensive land use (Hurtado-Salazar et al., 2016).

Goldschmidt (2014) discussed that, from the genetic point of view, grafting involves a complex system for the joining of two different genotypes, wherein each of which maintains its own genetic identity throughout the lifetime of the grafted plant. Recently, there have been claims that grafting may have genetic consequences because RNA exchange between scions and rootstocks occurs in the process.

In the splice grafting method, the rootstock stem is cut diagonally, removing the apical bud and a cotyledon. The same is done with a cut on the scion stem, leaving the bud with one or both cotyledons and cutting off their roots. Then the two stems are joined together, using a grafting clip. In the cleft grafting method, the rootstock is cross-sectioned below the cotyledons, and then the truncated rootstock stem is bisected to a depth of $1-2 \mathrm{~cm}$. The scion is cut below the cotyledons and the cut surface is trimmed to the shape of a wedge. The trimmed scion is inserted into the vertical slit of the rootstock and the graft is secured with a grafting clip. (Hurtado-Salazar et al., 2016). According to Guan \& Hallet (2016), these are the most used methods, for being low-input techniques, with most costs resulting from labor. The aim of this study was to evaluate the effect of grafting the commercial Chonto type tomato on cherry tomato introductions in terms of development, yield, and fruit quality of the grafted plant.

\section{MATERIAL AND METHODS}

The study was performed in a hydroponic greenhouse using the NFT (Nutrient Film Technique) recirculating system, at the Botanical Garden of the University of Caldas, at $2130 \mathrm{~m}$ above sea level, $19^{\circ} \mathrm{C}$ average temperature, and $75 \%$ relative humidity.

Three rootstocks of cherry tomato (IAC391, IAC426, and LA2076) and two ungrafted commercial scions (Torrano and Calima) were evaluated using two grafting methods (cleft and splice) (Table 1).

The materials were sown in 128-cell trays filled with Sphagnum peat number 3 . Grafting was carried out when the seedlings had four true leaves; the rootstocks used are introductions and the scions were the commercial varieties Calima and Torrano (Table 1). The experiment was arranged in a $(3 \times 2 \times 2)$ factorial randomized complete block design as follows: three rootstocks, two grafting methods, and two commercial scions. The experimental unit consisted of four plants with four replicates. Plants were spaced at $0.9 \mathrm{~m}$ between channels, $0.30 \mathrm{~m}$ between double rows, and $0.4 \mathrm{~m}$ between plants.

To ensure homogeneity, grafting was performed at 28 days after planting, when the rootstock and scion

Table 1: Genotypes of cherry tomato used as rootstocks and 'Chonto' commercial genotypes used as scions and their performance in yield and fruit quality

\begin{tabular}{lcc}
\hline Rootstock & Origin & Description \\
\hline *IAC391 & Brazil & T. red cherry \\
**LA2076 & Bolivia & T. cherry \\
*IAC426 & Brazil & T. red cherry \\
Torrano (ungrafted) & C.C Seminis & T. Chonto \\
Calima (ungrafted) & C.C Impulsemillas & T. Chonto
\end{tabular}

* IAC: Introductions from the Instituto Agronômico de Campinas, Campinas, Brazil.

** LA: Introductions from the Tomato Genetics Resource Center (TGRC).

Commercial scions Torrano and Calima 
seedlings had four true leaves and stem diameter from 2.5 to $3.0 \mathrm{~mm}$. Plants were grafted using two methods, cleft and splice. The cleft graft consisted of cross-sectioning the rootstock below the cotyledons, then bisecting it to a depth of $1 \mathrm{~cm}$. The scion was cut below the cotyledons and the cut surface was trimmed to a " $v$ " shape, then it was inserted into the vertical slit of the rootstock, and the graft was secured with a grafting clip The splice graft consisted of cutting the rootstock stem is diagonally, removing the apical bud and a cotyledon. The same was done with a cut on the scion stem, leaving the bud with one or both cotyledons and cutting off their roots. Then the two stems were joined together, using a grafting clip. After grafting, plants of both treatments were covered with $4 \mathrm{~cm} \times 10 \mathrm{~cm}$ plastic bags to avoid dehydration. In the acclimatization phase, the grafted seedlings were kept according to the methodology described by Guan \& Hallet (2016), for nine days.

The percentage of viable grafts was evaluated 10 days after grafting, which corresponded to 38 days after sowing the plants. The grafted plants were selected for the installation of the experiment, in which the subsequent evaluations were made.

To evaluate the development and vigor of the plants, the rootstock stem diameter was measured at $5 \mathrm{~cm}$ above the root collar ( $5 \mathrm{~cm}$ below the graft union), and the graft diameter, at $12 \mathrm{~cm}$ above the root collar $(2 \mathrm{~cm}$ above the graft union), using a $0.001 \mathrm{~mm}$ digital caliper. The compatibility of the rootstocks was evaluated according to Hurtado-Salazar et al. (2016).

Total production $\left(\mathrm{g}\right.$ plant $\left.{ }^{-1}\right)$, production per plant $(\mathrm{g})$, number of fruits per unit area, average fruit weight $(\mathrm{g})$, fruit quality variables (premium, first, second, <60 g), and loss percentage were evaluated according to Arbelaez et al. 2016.

The Hoagland \& Arnon (1950) nutrient solution, modified by Arbelaez et al. (2016), was used in the experiment.

Plants were irrigated every $1.5 \mathrm{~h}$, between 7:30 am and 4:30 am, with a duration of $22 \mathrm{~min}$ and an average flow of 3.25 L per min. The substrate consisted of a ten-centimeter layer of rice husks. The data obtained were evaluated by analysis of variance using SAS statistical software (SAS, 2013); and further, the Duncan's test for multiple comparison of means, at $5 \%$ significance level.

\section{RESULTS AND DISCUSSION}

\section{Graft-take percentage}

No significant differences were found after analyzing the variable graft-take percentage and its interaction with the rootstocks and type of scion, possibly indicating that the graft-take percentages directly related to the grafting method. Contrarily, significant differences were found when analyzing the interaction with the grafting methods cleft and splice, denoting graft-take percentages higher than $80 \%$ for both methods, which is considered good for this species (Table 2). For the production of grafted tomato seedlings, it is essential to obtain high graft success rates due to the high cost of the seed. A study by López et al. (2008), evaluating grafting methods in watermelon using squash plants as rootstocks, obtained similar results to this study, in which survival is related to the grafting method used.

During the grafting phase and nine days after the plants were acclimated, the graft-take percentage obtained with the cleft method was $98.3 \%$, showing significant differences from the splice method with graft-take percentage of $81.1 \%$. Zeist et al. (2017) evaluated different grafting methods in different solanaceous species and found that for mini-tomato rootstock 0224-53, RVTC 57 and RVTC 20, as well as wild species $S$. habrochaites var. hirsutum 'PI-127826', the approach method would be the best. They showed that the cleft method had the lowest graft-take percentage, which differs from the results of this study, since this method resulted in a higher grafttake percentage. This is possibly due to the larger surface contact of the scion with the rootstock, compared with the splice method. The slit made in the rootstock and the subsequent insertion of the scion fixed with the clip ensure greater contact between the vascular bundles, which is crucial to facilitate the formation of callus and determines the survival of the plant. In the splice grafting, the contact surface is smaller because the diagonal cut made on the stems of the scion and the rootstock and the subsequent joining of both generate a smaller contact surface, which in turn hinders the rapid formation of the callus and facilitates dehydration and, in some cases, the death of the plant. According to Vrsic et al. (2015), early compatibility in stages of crop development depends on factors such as environment, management of the graft, or even the combination rootstock-variety.

\section{Variables of compatibility}

Vigor - the diameter of rootstocks IAC391, IAC426, and LA2076 showed significant differences from the ungrafted controls (Table 3), but no statistical differences were found between rootstocks. Thus, grafted plants in any of the rootstocks had higher vigor compared with the ungrafted controls, as they showed larger diameters. Similar results were obtained by Hernández et al. (2014), who found that the average biomass of cucumber grafted on chilacayote produced greater accumulation of dry matter in stem and root, suggesting an increase in vigor, similar to that reported by Godoy et al. (2009), who found higher dry matter in grafted plants. 
We observed that grafted plants developed larger root systems (data not shown), which will grant a greater vigor to the plant, a feature that is desirable when problems arise from abiotic factors. López et al. (2008) argued that the vigor of a grafted plant is intermediate between the rootstock and the scion, although the influence of the former is greater. Grafted Torrano had the largest diameter, which is a desirable feature because a plant with good vigor is less likely to be affected by either biotic and abiotic factors.

Compatibility - all grafted plants showed positive compatibility (values $>1$ ), showing larger diameter in the rootstock than in the scion, which is desirable because, according to fluid mechanics, when a solute flows from a larger-diameter pipe to a smaller-diameter pipe, the pressure increases, thereby generating a rapid distribution of these solutes over the entire structure of the plant. A positive compatibility between the rootstock and the scion is indicative of physiological changes due to cellular interactions between two genotypes (Kokalis-Burelle et $a l .$, 2009). In a study by Farias et al. (2013), the same results were observed when grafting tomato on the rootstocks S. Gilo S. lycocarpum, S. stramonifolium, and $S$. viarum, obtaining positive compatibility (> 1) and indicating high-vigor rootstocks.

Negative compatibility occurs when the diameter of the scion is greater than the diameter of the rootstock and the diameter ratio is less than one $(<1)$, which is considered undesirable.

\section{Total production}

Significant differences were found $(\mathrm{p}<0.05)$ for the interaction of production with the different rootstocks. The highest yields per plant were recorded for the ungrafted control and rootstock IAC391, with values of 2915.2 and 2734.1 g plant $^{-1}$, respectively, followed by IAC426 and LA2076 with lower yields, 2517.7 and 2456.6 g plant $^{-1}$, respectively (Table 4). Leonardi \& Giuffrida (2006) grafted tomato hybrid Rita F1 on three commercial rootstocks and showed that one of the rootstocks excelled in yield compared with the others, which is consistent with our study. Also, Kunwar et al. (2014), evaluating the technique of grafting in tomato, noted that the yield of ungrafted treatments considerably outweighed treatments with grafting, regardless of the method, which does not agree with the data obtained in this study, in which rootstock IAC391 showed no significant differences when compared with the ungrafted control. Likewise, Bernal et al. (2016), who studied grafted string beans to improve performance in production, noted that one treatment obtained the best results for variable total yield per plant compared with other treatments, both grafted and ungrafted.

After analyzing the interaction of the production per plant with the different scions, significant differences ( $p$ $<0.05$ ) were found between ungrafted and grafted hybrid Torrano, with values of 3239.6 and 2793.0 g plant $^{-1}$, respectively. The same analysis between the scions of grafted and ungrafted hybrid Calima showed no significant differences ( $\mathrm{p}<0.05$ ), with values of 2590.8 and $2346.6 \mathrm{~g}$ plant $^{-1}$, respectively (Table 4$)$. Thus, the best scion in terms of production was hybrid Torrano, both grafted and ungrafted, with a difference of $547.6 \mathrm{~g}$ plant $^{-1}$ compared with Calima, grafted and ungrafted (Table 4). When this value is converted to 1 ha, this difference becomes 11.4 tons $\mathrm{ha}^{-1}$. The low production by Calima was possibly caused by the climatic conditions required for the hybrid to express its potential, as the temperature at the study site was around $19{ }^{\circ} \mathrm{C}$ and the favorable conditions for optimum development are above $23{ }^{\circ} \mathrm{C}$ (warm areas). Added to this is the high susceptibility to diseases such as Botrytis sp., which causes blossom drop.

The interaction of average fruit weight (AFW) with the rootstocks showed significant differences $(p<0.05)$, with the highest values recorded for the ungrafted controls, of $61.21 \mathrm{~g} \mathrm{plant}^{-1}$ (Table 4). This performance can be influenced by the low number of flowers per cluster (data not shown) of the ungrafted plants - inversely proportional as, in the presence of greater competition by a larger number of fruits, size and development will be significantly affected (Table 4). A study conducted in Mexico by Godoy et al. (2009), evaluating the effect of grafting on tomato plants, concluded that the grafted plants produced the largest fruits and the highest average fruit weights. These findings contradict the results of this study, in which the grafted plants showed the lowest values for this variable.

The average fruit weight of rootstocks IAC391, IAC426, and LA2076 showed significant differences from the ungrafted control (Table 4), but no significant differences were found among the rootstocks. Thus, the average fruit

Table 2: Duncan's test of multiple range for the variable graft-take percentage on the effect of grafting of commercial genotypes of tomato (Solanum spp.) on production and fruit quality

\begin{tabular}{|c|c|c|c|c|c|c|c|}
\hline \multirow[t]{2}{*}{ Variable } & \multicolumn{2}{|c|}{ ROOTSTOCK } & \multicolumn{3}{|c|}{ TYPE OF SCION } & \multicolumn{2}{|c|}{ METHOD } \\
\hline & IAC391 & IAC426 & LA2076 & TORRANO & CALIMA & CLEFT & SPLICE \\
\hline$\%$ YIELD & $90 \mathrm{~A}$ & $88.3 \mathrm{~A}$ & $90.8 \mathrm{~A}$ & $90.5 \mathrm{~A}$ & $88.9 \mathrm{~A}$ & $98.3 \mathrm{~A}$ & $81.1 \mathrm{~B}$ \\
\hline
\end{tabular}

* Means with different letters are significantly different $(\mathrm{p}<0.05)$. 


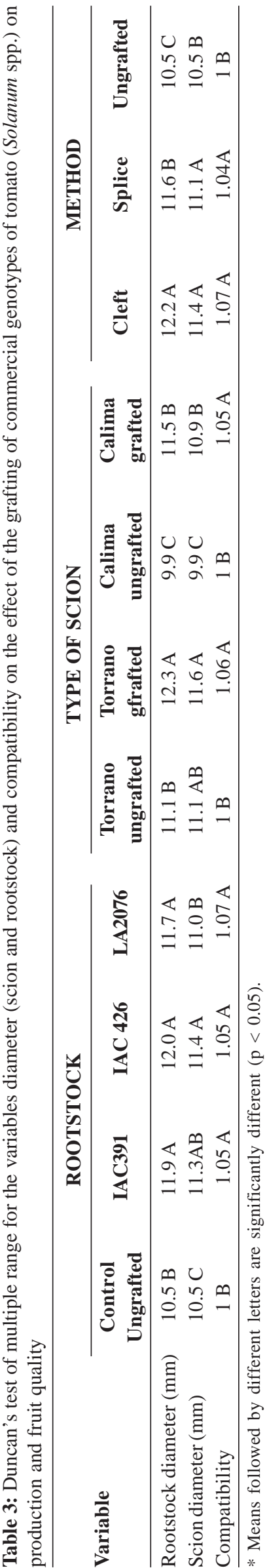

weight decreases when resorting to cherry rootstocks compared with the controls, which presented the highest average fruit.

On the other hand, significant differences were found when analyzing the interaction between the grafted and ungrafted scions (Calima and Torrano), in which ungrafted Calima showed the highest average fruit weight (63.775 g); it is noteworthy that fruits with this weight rank as top-quality fruits. The opposite occurred with the other interactions, which showed values lower than $60 \mathrm{~g}$.

The interaction of grafting method and average fruit weight showed no significant differences between the two methods (cleft and splice); however, significant differences were found when compared with the ungrafted control. Thus, the average fruit weight may be affected when using grafting compared with the ungrafted control, which obtained the highest values for this variable (Table 4).

\section{Fruit quality}

Soluble solids SS ( ${ }^{\circ}$ Brix) - 'Chonto' tomato production of hybrids Calima and Torrano grafted on cherry tomato showed an increase in soluble solids content of \pm 0.7 units compared with the commercial controls (Table 4). The rootstock with the highest soluble solids content was IAC426, with 3.87 units, followed by rootstocks IAC391 and LA2076 with 3.8 units each. It is noteworthy that the cherry tomato rootstocks had soluble solids content of 5.4 to 8.7 units (Herrera et al., 2015) and 'Chonto' tomato had 3.4 to 4.2 units (Carrillo \& Chávez, 2010).

The analysis of the interaction between grafted and ungrafted scions of 'Calima' and 'Torrano' showed that, when grafted onto cherry rootstocks, there was an increase in the content of soluble solids; in contrast, ungrafted scions did not show the same performance for this variable, as they presented lower values (Table 4). Cardoso et al., (2006), obtained the same results in a study on 'Chonto' tomato, in which the hybrid Cimabue (TO_1482) grafted onto variety Multifort presented significant values compared with the same ungrafted hybrid. In a study in southern Brazil, 'Oneco' tangerine was grafted on various rootstocks (Pereira et al. 2011), producing fruits with average ${ }^{\circ}$ Brix values of $8-12^{\circ}$, but when grafted on 'Rangpur' lime, 'Brix units decreased to $7.7^{\circ}$. 'Rangpur' lime is a rootstock that has a characteristic sour juice, like a lemon's, which generally has lower ${ }^{\circ}$ Brix; this highlights the direct influence of the rootstock on the scion, which is evidenced in this work.

The interaction for grafting method showed no significant differences between cleft and splice grafting, both achieving the highest means, but they differed from the ungrafted control (Table 4), confirming that there is a direct influence of grafting on the variable soluble solids content.

Rev. Ceres, Viçosa, v. 65, n.2, p. 150-157, mar/abr, 2018 


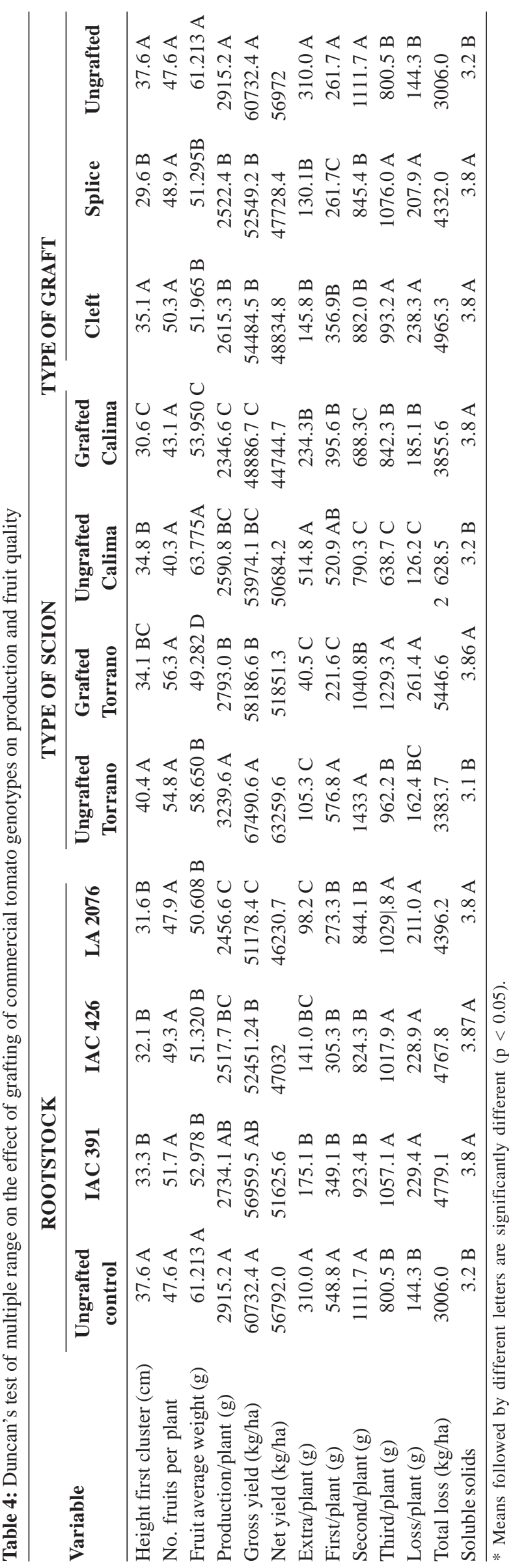

\section{Quality}

Extra Class - significant differences were found for tomato type extra and its interaction with the rootstocks. The ungrafted control obtained the highest means for this variable compared with the rootstocks (Table 4), while the rootstock with the lowest mean for this variable was LA2076, with $98.2 \mathrm{~g} \mathrm{plant}^{-1}$. The interaction of the scions with this variable showed significant differences between the scions, in which the highest means were obtained by ungrafted 'Calima', and no differences were found between the scions of 'Torrano' (Table 4).

The interaction with grafting method showed that significant differences with the ungrafted control, with means of $310 \mathrm{~g} \mathrm{plant}^{-1}$ for the extra class; however, no significant differences were found between the two grafting methods (Table 4).

First Class -the analysis of the variable first class fruits and its interaction with the rootstocks showed no significant differences between the rootstocks, but there was significant difference compared with the ungrafted control, which obtained the highest means for that variable with $548.8 \mathrm{~g} \mathrm{plant}^{-1}$ (Table 4). In the interaction of the scions with this variable, no significant difference was found between ungrafted 'Torrano' and 'Calima', and in turn they presented the most promising values for this interaction. Then, the interaction with grafting method showed differences between each method, highlighting the ungrafted control as the most promising for first quality fruits. One explanation for this result is that the grafted plants produced a greater number of flowers in some clusters, which, according to Hurtado-Salazar et al. (2016), evidences the relationship between supply and demand of carbohydrates, known as source-sink relationship. This translates in grafted treatments having a greater demand for carbohydrate, that is, a larger amount of fruits, which was the factor responsible for their decreased size.

Second Class - significant differences were found after analyzing the variable second class fruits and its interaction with the rootstock and grafting methods, in which ungrafted controls presented the highest values for both interactions; similarly, both rootstock and grafting methods showed no significant differences between them, possibly indicating that grafting influenced the reduction of second quality fruits. Significant differences were found for the interaction with the scions, in which ungrafted 'Torrano' presented the best results and 'Calima' showed the lowest means (Table 4).

Third-class no significant differences were found after analyzing variable third class fruits and its interaction with the rootstocks, but significant differences were shown regarding the ungrafted control. There was significant difference for interaction with the type of scion, in which grafted 'Torrano' had the highest mean of third class fruits, 
with $1229.3 \mathrm{~g}$, while ungrafted 'Torrano' and grafted 'Calima' showed no differences between them. Finally, ungrafted 'Calima' produced the lowest means of third class fruits, with $638.7 \mathrm{~g}$ (Table 4).

The interaction of this variable with the grafting method showed no significant differences between the two methods, but significant differences were found when compared with the ungrafted control (Table 4).

Loss percentage - significant differences were found for the variable loss percentage (weight $<30 \mathrm{~g}$ ) and its interaction with rootstock type, in which the ungrafted control showed significant differences from the rootstocks, but in turn, no differences were found among the rootstocks (Table 4). What stands out in that interaction is that lower losses are obtained in ungrafted treatments, when no rootstocks are used.

The interaction between variable fruit loss and the type of scion showed that the best combination for the lowest fruit loss is ungrafted 'Torrano' and 'Calima'; whereas the combination with the greatest fruit loss was grafted 'Torrano' (Table 4), which is not desirable in a production system, as the economic benefit would be highly affected. Finally, when analyzing the interaction of fruit loss with the type of grafting, no significant differences were found between the two methods, but differences were recorded when compared with the ungrafted control. It is noteworthy that this interaction resulted in less fruit loss when not using the grafting.

Height of first cluster - no significant differences were found after analyzing variable height of first cluster and its interaction with rootstocks, but significant differences were shown between these and the ungrafted control (Table 4). This demonstrates that the use of grafting reduces height of the first cluster, which is an important trait to consider in the production of tomato. The interaction between variable height of the first cluster and the type of scion showed that the best combination for obtaining plants with lower height of the first cluster is grafted 'Calima' with $30.6 \mathrm{~cm}$, although it showed no difference from grafted 'Torrano'. Likewise, ungrafted 'Torrano' presented the highest mean for this variable (Table 4), indicating again that grafting has a direct effect on the reduction in height of first cluster in tomato.

Finally, the analysis of the interaction of height of the first cluster with the type of grafting showed no significant differences between the cleft method and the ungrafted method, but differences arise in relation to the splice method, which showed the lowest mean height, with 29.6 $\mathrm{cm}$. This is opposed to the findings of Alvarez (2012), who studied the agronomic performance and incidence of diseases in grafted tomato plants and found no difference between grafted and ungrafted tomatoes in relation to the height of the first flower cluster.

The variables net yield and gross yield in the interaction rootstock $\times$ grafting method $\times$ scion (Figure 1 ) showed that the scion with the highest loss percentages for the variable fruit quality was 'Torrano', as it had the highest number of fruits per plant, exceeding other grafted and ungrafted scions. In the same way, its good yields offset its losses, as it stood out for the best results in every interaction evaluated for both gross and net yield. In summary, yields are much higher for the 'Calima' and 'Torrano' hybrids when not using grafting, since, as stated in this paper, grafting caused increased number of fruits per plant, which resulted in the reduction of fruit quality, that is, more fruit loss is generated in grafted plants.

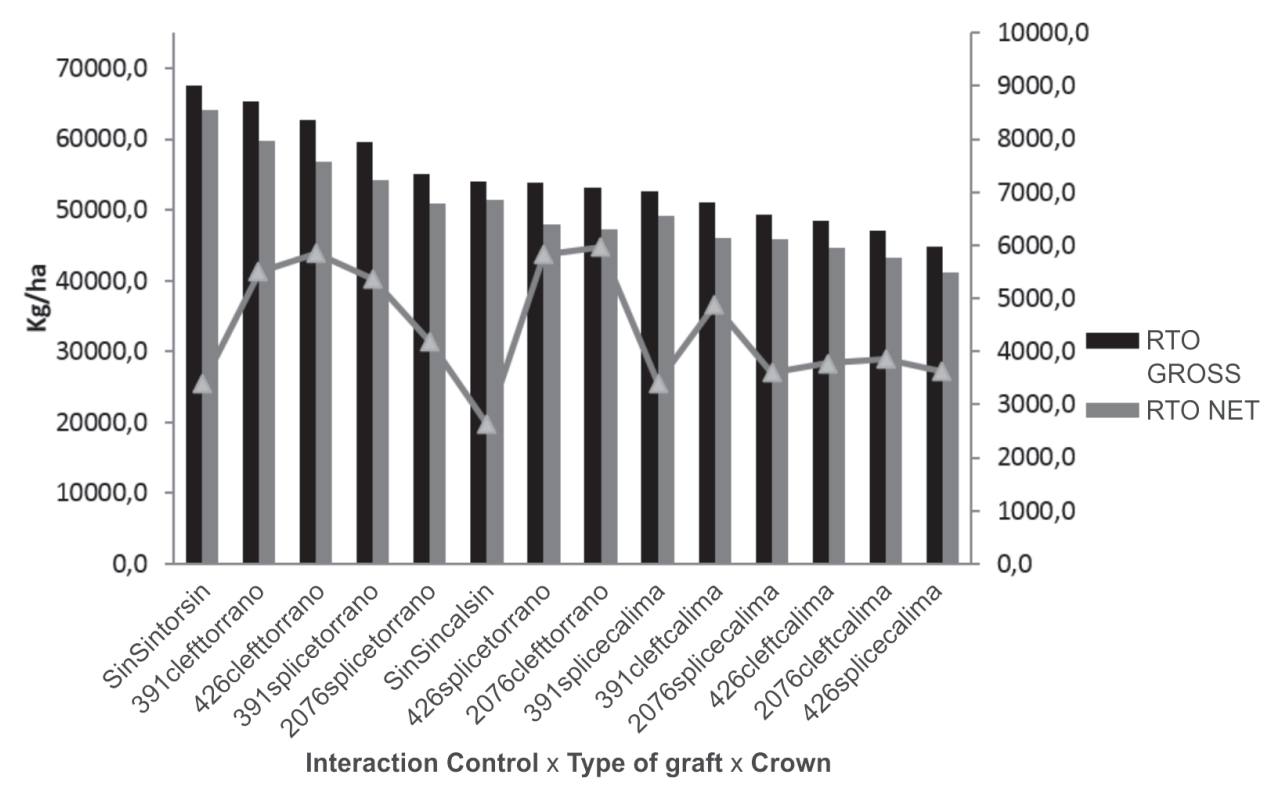

Figure 1: Duncan's test of multiple range for variables net yield (kg / ha) (RTO NET), gross yield (kg / ha) (RTO), and total loss (PERD) on the effect of grafting of commercial genotypes of tomato (Solanum spp.) on production and fruit quality. 
When comparing the ungrafted controls 'Torrano' and 'Calima', there was a difference of $\pm 13.5 \mathrm{tha}^{-1}$, since both are hybrids and under controlled conditions, therefore, their productive potential should be expressed to the maximum without presenting such a high difference.

\section{CONCLUSIONS}

The three rootstocks (IAC391, IAC426, and LA207) and the two methods of grafting (cleft and splice) showed positive compatibility (>1) for graft fusion.

The rootstock IAC391 showed the highest graft-take percentage and the highest production $\left(\mathrm{g} \mathrm{plant}^{-1}\right)$, similar to commercial controls. The cleft grafting method was the most promising, since it showed the highest graft-take percentage $(98.3 \%)$.

The rootstocks IAC391, IAC426, and LA2076 positively influenced the concentration of soluble solids of the fruits of the two commercial scions (Calima and Torrano).

The grafted plants yielded smaller fruits, meeting market standards, without affecting the final quality.

\section{REFERENCES}

Agronet (2016) Sistema de estadística agropecuaria-SEA. Available at: <http://www.agronet.gov.co/>. Accessed on: September $15^{\text {th }}$ 2016.

Alvarez J (2012) Comportamiento agronómico e incidencia de enfermedades en plantas de tomate (Solanum lycopersicum L.) injertadas. Acta Agronomica, 61:117-125.

Arbelaez L, Rivera J, Hurtado-Salazar A \& Ceballos-Aguirre N (2016) Technical and economic evaluation of three types of tomato nutrient solutions under semi-controlled conditions. Journal of Agricultural Science, 8:68-78.

Bernal J, Grimaldo O, Gonzalez D, Cervantes L, Rueda E \& Ceceña C (2016) El injerto como alternativa para mejorar el rendimiento en la producción de frijol ejotero (Phaseoulus vulgaris L.). Idesia, 34:43-46.

Cantu RR, Wilcken SR, Siciliano RJM \& Goto R (2009) Reação de porta-enxertos comerciais de tomateiro a Meloidogyne mayaguensis. Summa Phytopathologica, 35:216-218.

Cardoso SC, Soares AC, Brito AS, Carvalho LA, Peixoto CC, Pereira ME \& Goes E (2006) Qualidade de frutos de tomateiro com e sem enxertia. Bragantia, 65:269-274.

Carrer RF, Dianese EC \& Cunha MG (2015) Suppression of Fusarium wilt in tomato plants by rhizobacteria from the Bacillus genus. Pesquisa Agropecuária Tropical, 45:356-363.

Carrillo J \& Chávez J (2010) Caracterización agromorfológica de muestras de tomate de Oaxaca. Revista Fitotecnia Mexicana, 33:01-06

Faostat (2016) Agriculture Statistics on crops. Available at: <http:/ /faostat3.fao.org/home/index.html\#DOWNLOAD>. Accessed on: October $13^{\text {th }}, 2016$.

Farias AP, Ferreira RLF, Neto SEA, Costa FC \& Nascimento DS (2013) Organic production of tomatoes in the amazon region by plants grafted on wild Solanum rootstocks. Ciência e Agrotecnologia, 37:323-329.
FAO - Food and Agriculture Organization of the United Nations (2013) Faostat. Available at: 〈http://faostat3.fao.org/home/E >. Accessed on: 15 March 2016.

Godoy H, Castellanos J, Alcántar G, Sandoval M \& Muñoz J (2009) Efecto del injerto y nutrición de tomate sobre rendimiento, materia seca y extracción de nutrimentos. Terra Latinoamericana, 27:01-11.

Goldschmidt EE (2014) Plant grafting: new mechanisms, evolutionary implications. Frontiers in Plant Science, 5:1-9.

Guan W \& Hallet (2016) Techniques for Tomato Grafting. Available at: <https://extension.purdue.edu/extmedia/HO/HO-260-W.pdf >. Accessed on: April 15 $5^{\text {th }}, 2016$.

Hernández Z, Sahagún J, Espinosa P, Colinas M \& Rodríguez J (2014) Efecto del patrón en el rendimiento y tamaño de fruto en pepino injertado. Revista Fitotecnia Mexicana, 37:41-47.

Herrera H, Hurtado-Salazar A \& Ceballos-Aguirre N (2015) Estudio técnico y económico del tomate tipo cereza élite (Solanum lycopersicum L. var. Cerasiforme) bajo condiciones semicontroladas. Revista Colombiana de Ciencias Hortícolas, 9:290-300.

Hoagland DR \& Arnon DI (1950) The Water-Culture Method for Growing Plants without Soil. Berkeley, Agricultural Experiment Station. 32p. (Technical Bulletins, 347).

Hurtado-Salazar A, da Silva DFP, Picoli ET \& Bruckner CH (2016) Desenvolvimento, florescimento e análise morfoanatômica do maracujazeiro amarelo enxertado em espécies silvestres do gênero Passiflora. Revista Brasileira de Ciências Agrárias (Agrária), 11:323-329.

Hurtado-Salazar A, da Silva DFP, Sediyama CS \& Bruckner CH (2015) Caracterização física e química de frutos de maracujazeiro-amarelo enxertado em espécies silvestres do gênero passiflora cultivado em ambiente protegido. Revista Brasileira de Fruticultura, 37:635-643.

Kokalis-Burelle N, Bausher M \& Rosskopf E (2009) Greenhouse evaluation of Capsicum rootstocks for management of Meloidogine incognita on grafted bell pepper. Nematropica, 39:121-132.

Kunwar S, Paret M, Olson S, Ritchie L, Rich J, Freeman J \& McAvoy T (2014) Grafting using rootstocks with resistance to Ralstonia solanacearum against Meloidogyne incognita in tomato production. Plant Disease, 99:119-124.

Leonardi C \& Giuffrida F (2006) Variation of plant growth and macronutrient uptake in grafted tomatoes and eggplants on three different rootstocks. European Journal of Horticultural Science, 71:97-101

López E, Romo A \& Domínguez J (2008) Evaluación de métodos de injerto en sandía (Citrullus lanatus (thunb.) Matsum. \& Nakai) sobre diferentes patrones de calabaza. Idesia, 26:13-18.

Pereira M, Pacheco A, Brugnara E, Weiler R, Sartori I, Gonçalves J, João R \& Schwarz S (2011) Performance of 'Oneco' mandarin on six rootstocks in South Brazil. Pesquisa Agropecuária Brasileira, 46:406-411.

SAS Institute Inc. (2013) Statistical analysis system user's guide. Version 9.4. Cary, Statistical Analysis System Institute. 513p.

Van Dam P, de Sain M, Horst A, Van der Gragt M \& Rep M (2018) Use of comparative genomics-based markers for discrimination of host specificity in Fusarium oxysporum. Applied Environmental Microbiology, 84:e01868-17.

Vrsic S, Pulko B \& Kocsis L (2015) Factor influencing grafting success and compatibility of grape. Scientia Horticulturae, 181:168-173.

Zeist AR, Resende JTV, Giacobbo CL, Faria CMDR \& Dias DM (2017) Graft takes of tomato on other Solanaceous plants. Revista Caatinga, 30:513-520. 